Hodson, of the Esso Petroleum Co., Ltd., Fawley, in a paper ". . . written against a background of experience in the design of refinery process plant", discussed the difficult matter of "Design Philosophy in the Economic Selection of Materials for Process Plants", including questions of selection of suitable materials of construction, also methods of calculation for carrying out economic evaluations. "The Economic Life of Chemical Plant in the Nuclear Fuel Industry" was considered by G. K. Dickson, K. J. Norman and R. R. Gunton of the U.K. Atomic Energy Authority. In the nuclear industry, established in Great Britain barely fifteen years ago, evolution has had the effect of transforming what was initially a national defence project to one based on normal commercial practice. They stated that "such a rapidly and drastically changing situation has required constant re-appraisal of the economic life of the plants involved".

"Process Plant in the Gas Industry" was the title of a paper given by C. Stott (S.E. Gas Board), emphasizing some of the problems of plant design for meeting 'base' and 'seasonal load' demands (under statutory obligation), and latterly the widespread adoption of oil gasification plant to meet such conditions and to replace outdated plant. The final paper, "The Economic Life and Size of Process Plant in Underdeveloped Countries", by A. P. Shahbenderian, demonstrated how ". . . it is possible to assess the economically optimum life and, in particular cases, the optimum capacity of chemical plant for situations where the market is static or the rate of growth predictable".
H. B. MuLNer

\title{
THE TEASEL
}

$I^{\mathrm{T}}$ $T$ is one of the minor mysteries of modern crop husbandry that teasel growing should have survived in a restricted area of south Somerset when it has died out in all the former teasel-growing areas of Britain. About four hundred acres are now grown. Formerly, teasels appear to have been widely grown. Arthur Young reported teasel beds in Essex, where they were cultivated in rotation with medicinal plants like coriander, and there were acreages in Wiltshire and Gloucestershire. When it was that the hookended bract of the teasel flower head was first used to comb up the pile on cloth is not known, but the process almost certainly originated in the West Country to give the characteristic hard-wearing nap to West-Country broadcloth. It is probable, too, that the husbandry of teasel-growing was either begun, or at least received its first impetus to expansion and improvement, from the influx and settlement of the Huguenot weavers.

The broadcloth industry in the hinterland towns which teasel-growers served is now largely dead, but an isolated area around the Somerset villages of North Curry, Curry Rivel and Fivehead remains devoted to teasel husbandry. This has been examined by John L. Jones, who describes how acreage fluctuates from two to three hundred and the number of farmers participating is about fifty (Land, 11; Autumn, 1961). For most of them it is a crop which has been grown on the family farm for generations.

Why, then, has it survived? Where a highly specialized crop survives, climate and soil must obviously be right, and the heavy loams and moderate rainfall of south Somerset suit the teasel. Another unique aspect of the soil is that much of the land is 'teart' in the region of the country distinguished by an excess of molybdenum, which expresses itself as a copper deficiency in cattle. This in itself may be a specific ecological factor of the teasel. More possibly, it was the economic aspect of teart land farming which may have contributed to the survival of toasel-growing. For until it was appreciated that the serious cattle sickness associated with teart land could be rectified with modern treatment, the farmers concerned would have been more interested to retain any lucrative cash erop for which their land was suited than those with sound and healthy land would have been to grow teasels. Added to this is the con- tinuity of husbandry and the skill and specialized knowledge acquired in centuries of growing.

The superiority of the teasel - the fuller's teasel, as it was formerly called-lies in the supple hookends of the bracts or awns of the cylindrical flower-heads. To-day all the Somerset teasels are bought for the northern cloth-finishing mills, where they are used to produce the brushed effect on the best-quality face cloths. For these the action of the finest wire brushes is too severe.

The teasel crop begins as a fine seed sown in drills in the spring. The early husbandry is as for roots, and the crop is hand-hoed to keep down weeds and afterwards singled out to 4 in. apart. By the end of autumn the plants are ready for transplanting - the teasel is a biennial-and lifted with a special tool called a 'spitter', which severs the long tap root. They are dibbled on to the ploughed furrow at a rate of twelve thousand plants to the acre. The convention is $30 \mathrm{in}$. between the rows and $24 \mathrm{in}$. between the plants. During this second year the plants throw out big central stems and side branches surmounted by prickly heads, which are ripe for the teaselling knife in August.

The teasel is one of the latest crops to receive the benefits of modern crop protection, which has considerably increased the yields from the fields of the more progressive growers. Squat malformed plants producing soft teasels with numerous 'dead head' plants as well had long been a mysterious problem in the Somerset teasel beds. Long field rests did nothing to help. Then the eel worm was isolated as a major teasel pest, which explained why resting between crops for long periods had not helped. The pest was being perpetuated in the soil by other crops such as oats, mangolds and beans, and on numbers of hedgerow hosts such as cleavers and chickweed. It was also being transmitted by infested seed, and teasel seed can now be pre-treated like clover to kill the pest. The growing crop may also need dusting against the teasel leaf miner-small egg-laying black-flies which hatch maggots on the leaves and cause bacterial rots. Not so easily handled, but rarely occurring, are attacks by the cucumber mosaic virus which causes leaf mottling and stunted growths, and the fungus of violet root rot, which destroys the tap root and starves the plant of nutriment. 